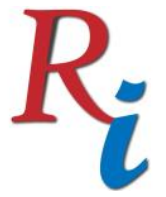

Asia Proceedings of Social Sciences

(APSS)

www.readersinsight.net/APSS

\title{
EVALUATION OF REGIONAL FINANCIAL MANAGEMENT \\ TRAINING PROGRAMS
}

Muhammad Ridha Albaar*

Post Graduated Universitas Negeri Jakarta

Departmen of Educational Technology Universitas Negeri Jakarta

Indonesia

\section{Zulfiati Syahrial}

Departement of Education Technology

Universitas Negeri Jakarta

Indonesia

\section{Maria Paristiowati}

Departemen of Educational Chemistry

Universitas Negeri Jakarta

Indonesia

*Corrosponding author's Email: muhammadridha_tp15s3@mahasiswa.unj.ac.id

Peer-review under responsibility of $3^{\text {rd }}$ Asia International Multidisciplanry Conference 2019 editorial board

(http://www.utm.my/asia/our-team/)

(C) 2019 Published by Readers Insight Publisher,

lat 306 Savoy Residencia, Block 3 F11/1,44000 Islamabad. Pakistan,

info@ readersinsight.net

This is an open access article under the CC BY-NC-ND license (http://creativecommons.org/licenses/by-nc-nd/4.0/). 


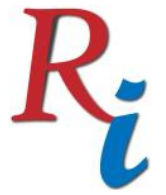

\title{
Asia Proceedings of Social Sciences
}

\author{
(APSS) \\ www.readersinsight.net/APSS
}

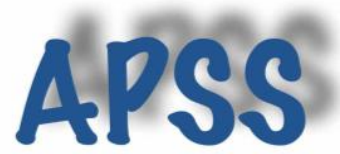

\section{Rese a r ch H i g h I igh t s}

The purpose of this study was to determine the effectiveness of the Regional Financial Management training program at the Human Resources Development Agency of North Maluku Province. This study is a program evaluation study that usesmodel four level Kirkpatrick'swhich includes the level of reaction, learning, behavior and results. In this study discussed the level of reaction at four levels. The reaction level is discussed about the training participants' reactions to the curriculum, education staff and training facilities. The curriculum components are discussed about training schedules, training materials, learning methods and media. In the education and training component, the reaction of the resource person and the training committee was discussed. The components of the education and training facilities are discussed about classrooms, dormitories, supporting facilities for training and consumption of education and training. This study produces recommendations for reaction levels that can be used as references to improve the quality of the Regional Financial Management Training Program at the Human Resources Development Agency of North Maluku Province.

Keyword: Evaluation, Reaction Level

\section{Research Objectives}

In the development and implementation of the state, the Indonesian government is faced with national guidance and global challenges to achieve good governance. Therefore, it is needed human resources or apparatus that has competence as an asset of the nation and state in carrying out development both nationally and regionally.

Civil Servants (PNS) have a role that determines the success of implementing national and regional development. Civil servants who are able to carry out this role are civil servants who have the competence indicated by their attitudes and behavior that are full of loyalty and obedience to the state, good moral and mental, professional, aware of their responsibilities as public servants, and able to become an glue of national unity.

Competent apparatus resources are needed in the governance system in accordance with national guidelines and global challenges. The issue of apparatus competency is an important determinant considering that the apparatus has a double duty, in addition to being a fair and transparent community service and must also be able to demonstrate loyalty, dedication and work ethic and high integrity.

Competency development as intended in Law Number 5 of 2014 article 69233 includes (a) technical competence, measured from the level and specialization of functional technical education and training, and technical working experience; (b) managerial competence, measured from the level of education or structural or management training and leadership experience; and (c) socio-cultural competence measuredfrom work experience related to pluralistic communities in terms of religion, ethnicity and culture so that they have national insight, while Law Number 23 Year 2014 in addition to the three competencies contained in Law Number 5 Year 2014 adds one competency namely the competence of government is the ability to work based on the knowledge and skills in the fields of development, governance and community empowerment as well as the attitudes that must be fulfilled by each ASN to obtain work in accordance with its main tasks and functions.

Along with the implementation of Law Number 5 of 2014 concerning the State Civil Apparatus that at present, education and training of apparatus is faced with several issues including (1) education and training have not been fully related to the demands of improving performance at 


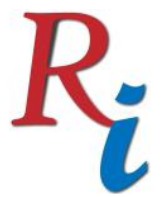

\title{
Asia Proceedings of Social Sciences
}

\author{
(APSS) \\ www.readersinsight.net/APSS
}

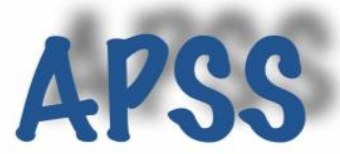

the individual, group level, or organizational level; (2) education and training have not been fully integrated with PNS career development; (3) education and training have not been carried out according to the education and training management cycle.

The model developed by Fitzapatrick can measure various components of the effectiveness of achieving the objectives and targets of the Regional Financial Management Training, such as the suitability of the material with the needs of training participants, widyaswara / narrator performance, availability of facilities and infrastructure, and the effectiveness of learning activities in shaping work behavior and equipping participants with competencies needed, and how the impact of education and training on participants' workplaces after they return to their respective work units. The focus of the research will be examined in this research is: How Reaction(reaction) participants towards Regional Financial Management training (Fitzapatrick, 2012).

There are several definitions that the evaluation experts put forward regarding what is meant by evaluation. An evaluation in English is known as the "Evaluation" which is then absorbed into the Indonesian language treasury; for the success of a program. There are several sources that can be used as references, one of which was quoted by Arikunto (Arikunto, 2010), among others in the Oxford Advanced Learners Dictinoary Of Current English dictionary (AS Homby, (1986)) states that evaluation is to find out, deciding the amount or value; which states that evaluation is an attempt to determine the value or amount. Furthermore according to Gronlund as quoted by Djaali and Muljono that evaluation is a systematic process to determine and make decisions, to what extent the goal or program has been achieve (Muljono, 2008).

\section{Methodology}

The approach used in this study is a qualitative research approach with evaluative research methods. The research design used in this study is the evaluation of this program is Krikpatrick or also called the four-level evaluation model. The Krikpatrick model focuses on the level of reaction.

\section{Results}

One type of strategic education and training to realize civil servants as part of a professional and competent State Civil Apparatus (ASN) is through technical training.

Before explaining the results of the evaluation, first described the characteristics of participants in the Regional Financial Management Training at the Human Resources Development Agency in North Maluku Province. Training participants are ASNs who are placed in the financial section of the government of North Maluku Province. Participants consist of 22 men or 55\% and 18 women or $45 \%$. The total number of training participants is 40 people.

The rank and position of the training participants varies from group II consisting of 3 participants or $7.5 \%$, class III consists of 36 participants or by $90 \%$, and group IV consists of 1 participant or $2.5 \%$. The total number of training participants based on groups is 40 people.

\section{Findings}

Based on the results of the research, the following points need to be carried out at the Regional Financial Management Training providers at the Human Resources Development Agency of North Maluku Province:

1. Establish standardization of facilities and infrastructure in the implementation of regional financial management training. 


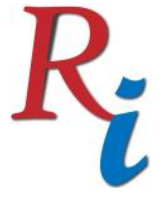

\title{
Asia Proceedings of Social Sciences
}

\author{
(APSS) \\ www.readersinsight.net/APSS
}

2. Establish a standard and selective in assigning resource persons / lecturers from BPSDM to improve the competence of resource persons from BPSDM North Maluku.

3. Improvements to the effectiveness of learning regional financial management training in accordance with the learning objectives.

4. Organizers provide maximum service to participants

5. Organizers provide facilities and infrastructure in accordance with established standards.

6. Providing complete training materials to support the learning process.

\section{Acknowledgement}

This research work is supported by North Molucas Provincial Government

\section{References}

Arikunto, S., 2010. Research Procedure A Practical Approach. Jakarta: Rineka Cipta.

Fitzapatrick, J.L. et al, 2012. Program Evaluation, Alternative Approaches and Practical Guidelines. Pearson: Boston.

Muljono, D. dan P., 2008. Pengukuran Dalam Bidang Pendidikan. Grasindo, Jakarta. 